\title{
DURATION OF HORMONAL CONTRACEPTIVE USE AND ITS CORRELATION WITH BLOOD PRESSURE
}

\author{
Mumpuni Intan Pertiwi, Niken Meilani, Yuliantisari Retnaningsih
}

Study Program in Midwivery, Health Polytechnics, Ministry of Health Yogyakarta

\begin{abstract}
Background: Over few past decades, oral contraceptive containing estrogen has been commonly and routinely preferred by women of reproductive age. Studies have reported current hormonal contraceptive use is associated with adverse cardiovascular outcomes, including high blood pressure. This study aimed to examine duration of hormonal contraceptive use and blood pressure.

Subjects and Method: A cross sectional study was conducted in Gunungkidul, Yogyakarta, Indonesia. A number of 115 women of reproductive age with hormonal contraceptive was selected randomly. The dependent variable systolic blood pressure. The independent variable was hormonal contraceptive. Data on hormonal contraceptive was obtained from family planning register card. The other variables were collected by questionnaire. The data were analyzed by a multiple linier regression.

Results: Hormonal contraceptives uptake in 2 years elevated systolic blood pressure $(\mathrm{b}=1.32 ; 95 \% \mathrm{CI}=0.36$ to $2.29 ; \mathrm{p}=0.007)$ after controlling systolic blood pressure 2 years ago, age, and body mass index.

Conclusion: Hormonal contraceptives uptake in 2 years elevated systolic blood pressure in women of reproductive age.

Keywords: hormonal contraception, systolic blood pressure, women of reproductice age

\section{Correspondence:}

Mumpuni Intan Pertiwi. Study Program in Midwivery, Health Polytechnics, Ministry of Health Yogyakarta. Jl. Tatabumi 3, Banyuraden, Gamping, Sleman, Yogyakarta. Email: mumpuni.ip@gmail.com. Mobile: +6285325638182
\end{abstract}

